\title{
Access and Use of Mobile Phone in Daily Life Activities by Rural Women of Gilgit-Baltistan, Pakistan
}

\author{
Sabit Rahim (D, Sadruddin Bahadur Qutoshi, Syeda Abida, Faqeer Muhammad, \\ and Imtiaz Hussain \\ Karakoram International University, Gilgit-Baltistan, Pakistan \\ Correspondence should be addressed to Sabit Rahim; sabit.rahim@kiu.edu.pk
}

Received 13 March 2020; Revised 19 May 2020; Accepted 25 May 2020; Published 13 June 2020

Academic Editor: Fawad Zaman

Copyright (C) 2020 Sabit Rahim et al. This is an open access article distributed under the Creative Commons Attribution License, which permits unrestricted use, distribution, and reproduction in any medium, provided the original work is properly cited.

\begin{abstract}
This study aims to investigate the access to a mobile phone, usage pattern, and its impact on mountainous rural women of two districts, i.e., Hunza and Nagar districts of Gilgit-Baltistan, Pakistan. To attain the objective of the research, the researchers have employed various statistic methods, and data were collected through a questionnaire from 190 respondents in the study area (200 respondents were selected). Initially, Kaiser-Meyer-Olkin (KMO) and Bartlett's tests were used for sampling adequacy, and factor analysis technique was used to explain correlations among multiple outcomes. The results revealed that $80 \%$ of women in the Hunza and Nagar districts own mobile phones (access) and 63\% have good skills of mobile phone usage for a variety of purposes. Moreover, $56.4 \%$ of women use mobile phones in their daily life activities; however, $23.6 \%$ disagreed with the statements. On the contrary, the results show that $71.8 \%$ women use mobile phones for security purposes. Therefore, the study recommends that effective use of the mobile phone in daily activities of mountainous rural women can be one of the effective strategies to boost their confidence level and feeling of security. Finally, socioeconomic development of the area is possible by providing technical skills related to mobile phone business to the unskilled women of the two districts.
\end{abstract}

\section{Introduction}

Information and communication technology (ICT) in today's world comprise applications and communication tools, such as social media [1], digital information repositories either online or offline, and digital photography and video, and among them, the mobile phone is becoming the most prominent tools of technology [2-5]. As the mobile phone is refashioning the lives of its users regardless of their socioeconomical and gender differences, the rural mountainous women cannot be excluded $[5,6]$. The mobile phone, as one of the mostly used tools of ICT, has been recognized worldwide as an effective and efficient tool used for multiple purposes [6,7]. This technological tool has a positive impact on the lives of its users especially people living in rural [7] and deprived areas like mountainous regions by connecting them with the information society [8]. Thus, it has revolutionized the life of its users in the field of development.
On the contrary, according to the GSMA, two billion women in developing countries do not own mobile phones. Likewise, women are $26 \%$ less likely than men to own a mobile phone. The situation is even worst in South Asia, where women on average are $38 \%$ less likely to own a mobile phone than men [9]. According to the World Bank data, Pakistan falls under the lower-middle-income group with a population of 212 million of which $60 \%$ live in rural areas (Pakistan Census Report, 2017). However, in 2018, it was reported that the percentage of fixed-line phone subscribers was $1.3 \%$, while the mobile phone subscribers were $74 \%$ [10-12].

Thus, in Pakistan the access to mobile phone services in its primitive phase and limited to provide only voice communication facilities within cities. However, over time, this technology has revolutionized the lives of people [13] in one way or the other. When we look back in history, the mobile phone culture came to Pakistan in 1994 with the introduction of some cellular networks. Now, out of two, the 
second person owns a mobile phone in the world, and onethird of the population in Pakistan possesses a mobile phone [14]. The recent forms of mobile phone services enabled mankind to enjoy a diverse range of facilities such as text messages, multimedia messages, online payment, banking, online shopping, web surfing, financial transactions, and the diverse kind of social engagements $[15,16]$.

These opportunities opened new doors to both males and females to interact with each other and engage in socioeconomic activities such as how to help rural women to improve their socialization and economic development [8]. Studies revealed that these technological tools have enabled rural women to use technology in business activities [17]. At the same time, access and usage have increased very rapidly in developed as well as in the developing countries for the last fifteen years. This technology has brought huge changes in the lives of people, more quickly than any previous technology [18] along with several challenges as well.

People in developing countries, including Pakistan, face several developmental challenges due to economic and cultural barriers and rural and urban gaps [19]. Likewise, low literacy, poor healthcare facilities, low per capita income, a high degree of poverty, and poor infrastructure are common in most developing countries including Pakistan [16]. In the rural and mountainous areas, the mobile phone has emerged as an important development tool. For instance, people access health facilities, economic development (publicize their products), and transfer amount using mobile banking [20]. It is seen as a device that has the potential to break the rural-urban digital divide and the developmental gap by delivering information on a variety of economic and social issues. In Hunza and Nagar districts, the landline phone is not used to the extent that the mobile phone has revolutionized with extraordinary growth as one of the most accessible and affordable ICT tools. Today, all over the world, its expansion in a very short period provided multiple opportunities for its users to access each other [16]. However, access to mobile phones and its impact on rural mountainous people, especially in the context of Hunza and Nagar, has not been substantiated empirically.

Therefore, this paper aims to explore the socioeconomic impact of mobile phones on rural women of the two districts, i.e., Hunza and Nagar. This region has geopolitical and strategic importance due to the China-Pakistan Economic Corridor (CPEC) which connects China and Pakistan. To this end, how the women population of this region has been exposed to this technological tool plays a vital role to predict the future development associated with the CPEC. This study provides an opportunity and policy recommendations to stakeholders on the role of mobile phone technology in women's development in mountainous areas.

1.1. Objectives of the Study. The objectives of this study are as follows:

(1) To explore the access to the mobile phone by rural women across the two districts of the Gilgit-Baltistan province $[1,21,22]$
(2) To examine the differences in the usage pattern of the mobile phone by rural mountainous women of the two districts of the Gilgit-Baltistan province $[4,23,24]$

\section{Review of Relevant Literature}

2.1. Access to Mobile Phone and Preferences. The study of the UN's International Telecommunication Union (ITU) reports that men users of mobile phones are greater than the women in most countries including Pakistan [12, 25]. Most of the women in developing countries do not have mobile phones because of cultural restrictions and a male-dominated society [26]. However, Pakistan has the highest gender gap of mobile ownership with women $37 \%$ less likely than men to own a mobile phone and Bangladesh was the second highest at 33\% [9].

However, the mobile phone provides greater facilities in life such as connecting with friends and family, taking selfies and photos, getting financial independence [17], seeking employment opportunities, finding family health and educational venues [27], accessing the Internet and government services, feeling secure, and accessing information [28, 29]. As access to mobile phones and the Internet grows, ICTs are playing an ever-stronger role in efforts aimed at improving the lives of people, especially women $[13,30]$. There are some psychological and other barriers such as gender discrimination [31], lack of confidence [32], language difficulties, low literacy [33], and lack of time and money which prevent women and young girls from taking full advantages of the technology [34].

Thus, along with these barriers, technology adoption in rural Pakistan appears to be a challenging situation to promote ICT skills and women's access to this technology in rural areas [35]. However, some steps need to be taken towards ICT adaptation such as educating women on ICTs, recruitment drive (equal opportunity for males and females), mentoring schemes, and equal opportunities to business (pay, respect, leadership, no discrimination, and flexible work schedules) [8]. In doing so, women can improve their access to ICTs and use these tools to move towards reaching their full potential [36]. The limited access to technology for the women of rural areas of Pakistan, for many reasons as mentioned above, appears to be different in the case of [37] Hunza and Nagar districts.

\subsection{Mobile Phone Supports Rural Women in Their Daily} Activities. Studies support the view that the mobile phone empowers women to participate in socioeconomic services [19], report familial violence, consult family planning agencies [38], access education, health care, and financial services [39], and enable them to develop their value of life and that of their families [9]. Unlike other ICT devices, the mobile phone does not require literacy or sophisticated skills. That may be one of the reasons why women can easily use a mobile phone to manage, uphold, change, and contribute to the affairs of the socioeconomic life [40]. In every society, the mobile phone has introduced new ways for 
economical activities $[15,20,34]$ due to its easiest and quickest flow of information. For instance, it offers quick access to educational, cultural, social, sports, and financial events all over the world at any time in any place [41, 42].

In some of the developing countries, women face problems to own mobile phones for many reasons including cultural, gender, and attitudinal factors [39, 43]. However, in the case of Hunza and Nagar districts, the women use a mobile phone for accessing information and sharing ideas, for business purposes and other socioeconomic activities that are different as compared to other parts of the developing world [44].

The literature argues that effective use of mobile phones can change the lives of the people in general and rural mountainous women in particular in the areas of business (MMS, 3G, 4G, and portability) and other activities [16, 45]. Thus, in the context of Hunza and Nagar districts, women's use of mobile phones for business activities cannot be ignored $[46,47]$. However, there are many social benefits of mobile phones such as peace of mind, protection, increased personal security, better social life, the aftereffect of a calamity, and productive tool at work [48]. However, there are many challenges along with the new opportunities coming at the doors of these rural mountainous women. CPEC is one of those opportunities which can also bring many challenges as well, if not well prepared to face those challenges and convert them into meaningful life-enhancing opportunities.

2.3. Gender and Age-Wise Differences of Mobile Phone Usage for Safety and Security Purpose. Mobile phone is an empowering technological tool that offers multiple opportunities to both males and females equally, depending upon the level of individuals' exposure, sociocultural, and other barriers on the way to access this technology. For example, rural mountainous women, within their own limits, can use it for doing small businesses, to keep themselves secure from possible risks, to create a learning environment, and to eliminate gender income variation gaps [49]. It is believed that the use of a mobile phone can play a vital role in education, safety, and security [23]. Thus, the accessibility of a mobile phone, especially by young women (e.g., universitylevel girls and women doing jobs), is now becoming a priority matter to achieve their objectives [50] such as connecting, accessing knowledge [7], doing business, and improving safety and security matters. [6] Moreover, the advancement in the mobile phone technology brought challenges and difficulties for the elder users as compared to younger users [51]. In the same line, the authors in [5] listed the mobile phone users in groups and studied their behaviors towards mobile phones such as cost consciousness, safety conscious, mobile-dependent users, sophisticated users, and practical uses.

Both male and female students of GB are taking advantage of the use of mobile phones like mutual activities through SMS, listening lectures, sharing information, and educational applications (like a mobile dictionary) [52]. Students easily share thoughts and information with each other [53,54]. Students use mobile phone devices to upload and post their academic data on course websites, and each student gets access to their course [21, 22]. Many boys and girls use a mobile phone as a symbol of identity that help them to be independent in their interactions within and outside the family and to reinforce their identity [55].

\subsection{Research Questions}

(1) Do the women of Hunza and Nagar districts have access to the mobile phone and have enough skills to use it?

(2) What are the different usage patterns of the mobile phone adopted by the women of Hunza and Nagar?

\section{Methodology}

3.1. Theoretical Framework. The following theoretical framework is the concept map that provides a guideline for researchers to follow accordingly. Based on the previous literature, we developed a theoretical framework as shown in Figure 1. Four major categories were identified such as mobile phone (MP) access, skills to use MP, use in daily life activities, and use for safety and security purposes due to prevailing security threats in Pakistan.

3.2. Sample and Procedure. A survey was carried out to collect the data from female research participants from Hunza and Nagar districts of GB, Pakistan. For this purpose, the researchers developed a questionnaire consisting of 31 items with two major sections. Further, Section A consisted of two subsections: the first subsection contains demographic data (age, the region of origin, and qualification) and the second subsection contains the access to the mobile phone, types of mobile phones, mobile phone brand, and service provider. Before the distribution of questionnaires to the participants, 5 students and 2 faculty members from the university (i.e., the research site) were asked to review the questionnaires. The purpose of this pilot testing was to find the level of difficulty in understanding the questions by the respondents. As a result of this testing, few items were rephrased for a better understanding of questionnaires. A reliability test was performed, and Cronbach's alpha value is 0.972 which is an acceptable level of internal consistency.

200 female participants were selected using a random sampling procedure from the two districts of GB and 190 responded. All participants were asked to fill the consent forms that helped the researchers to use these consent forms as alternatives to research approval from the Ethics Committee of the university. Because there does not exist such a kind of body in the university (Table 1 shows the result).

In the second subsection of $\mathrm{A}$, the participants were also asked questions regarding access to the mobile phone, kinds of mobile phone (simple mobile or smartphone), mobile phone brand, and service providers they use (results are shown in Table 2).

Section B: the section B has been divided into three parts such as skills to use the mobile phone, using the mobile phone in daily life activities, and using the mobile phone for 


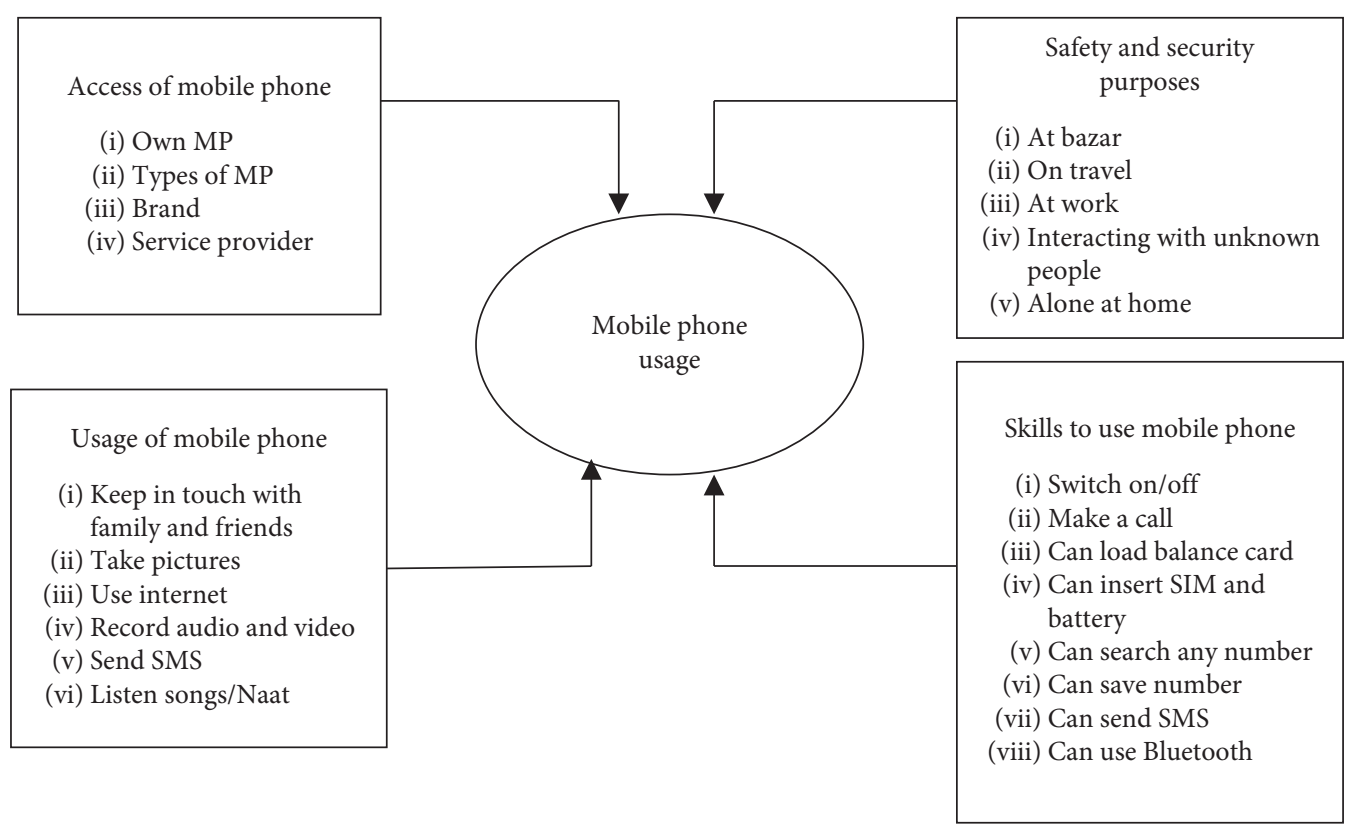

Figure 1: Theoretical framework [1-3].

TABLE 1: Respondents' profile.

\begin{tabular}{lcccc}
\hline \multirow{2}{*}{ Age of respondents } & \multicolumn{2}{c}{ Hunza } & \multicolumn{2}{c}{ Nagar } \\
& $N$ & $\%$ & $N$ & $\%$ \\
\hline 20 to 25 & 13 & 7 & 17 & 9 \\
26 to 30 & 34 & 18 & 22 & 12 \\
31 to 35 & 31 & 16 & 40 & 21 \\
36 to 40 & 17 & 9 & 16 & 8 \\
\hline Qualification of respondents & & & \\
No education & 54 & 28 & 55 & 29 \\
Below middle & 4 & 2 & 3 & 2 \\
Below 10 & 9 & 5 & 5 & 3 \\
Below 12 & 13 & 7 & 18 & 9 \\
Bachelors & 10 & 5 & 12 & 6 \\
Masters and above & 5 & 3 & 2 & 1 \\
\hline
\end{tabular}

safety and security purposes by the women of Hunza and Nagar (shown in Table 3).

This part indicates that how the women of Hunza and Nagar use the mobile phone in their daily life activities. A 5-point Likert scale ranging between $1=$ strongly disagree $(\mathrm{SDA}), 2=$ disagree (DA), $3=$ somehow agree (SA), $4=$ agree (A), and $5=$ strongly agree (SA) were used to indicate the respondents agreement on the statements (results are shown in Table 4).

In Section B, the respondents were asked 5-point Likert scale questions regarding the use of the mobile phone for safety and security purposes (results are shown in Table 5).

\section{Results}

The Statistical Package of the Social Sciences (SPSS 23.0) was used to analyze the data. For sections A and B initially, descriptive statistics were used to analyze the data to find a percentage. Similarly, Kaiser-Meyer-Olkin (KMO) and Bartlett's tests were used for sampling adequacy, and factor analysis technique was used to explain correlations among multiple
TABle 2: Percentage of access of the mobile phone by the women of Hunza and Nagar.

\begin{tabular}{lcc}
\hline Questions (1-3) & Hunza & Nercentages \\
& & \\
Do you have mobile phone? & 10.5 & 9.5 \\
No & 39.5 & 40.5 \\
Yes & \\
\hline What kind of mobile phone do you have? & 31.1 \\
Simple & 31.6 & 9.5 \\
Smart & 7.9 & \\
\hline How many smartphones do you have in your family? & \\
Only one & 16.1 & 12.5 \\
2 to 4 & 13 & 8.9 \\
5 to 7 & 1 & 0 \\
\hline Questions (3-4) & \\
Mobile phone brand & & \\
Nokia & 3.2 & 7.4 \\
Samsung & 0.5 & 2.1 \\
Qmobile & 19.5 & 15.8 \\
BlackBerry & 0 & 1.6 \\
1 and 3 & 11.6 & 10.5 \\
2 and 3 & 3.2 & 1.6 \\
1 and 2 & 1.6 & 1.6 \\
\hline Which is your service provider? & & 12.6 \\
SCOM & 2.6 & \\
Telenor & 9.5 & 15.3 \\
Zong & 12.1 & \\
More than 1 & & \\
\hline
\end{tabular}

outcomes such as mobile phone access, use in daily life activities, skills to use, and use for safety and security purposes.

4.1. Demographic. In this research study, 200 female participants were selected by employing a random sampling procedure from the two districts of GB and 190 responded. 
TABle 3: Percentage of mobile phone usage skills of the women of Hunza and Nagar.

\begin{tabular}{|c|c|c|}
\hline \multirow{2}{*}{ Questions (1-5) } & \multicolumn{2}{|c|}{ Percentages } \\
\hline & Hunza & Nagar \\
\hline \multicolumn{3}{|c|}{ Can switch on/off mobile phone } \\
\hline No mobile & 10.5 & 9.5 \\
\hline Yes & 39.5 & 40.5 \\
\hline \multicolumn{3}{|c|}{ Make a call without help } \\
\hline No & 6.3 & 1.6 \\
\hline Yes & 33.2 & 38.9 \\
\hline \multicolumn{3}{|c|}{ Can load balance card } \\
\hline No & 16.3 & 11.1 \\
\hline Yes & 23.2 & 29.5 \\
\hline \multicolumn{3}{|c|}{ Can insert and change SIM card } \\
\hline No & 7.9 & 2.6 \\
\hline Yes & 31.6 & 37.9 \\
\hline \multicolumn{3}{|c|}{ Can charge my mobile phone } \\
\hline No & 1.1 & 0.5 \\
\hline Yes & 38.4 & 40 \\
\hline \multicolumn{3}{|l|}{ Questions (6-10) } \\
\hline \multicolumn{3}{|c|}{ Can insert mobile battery } \\
\hline No & 5.8 & 3.2 \\
\hline Yes & 33.7 & 37.4 \\
\hline \multicolumn{3}{|c|}{ Can enter and save number of any person to my contact list } \\
\hline No & 21.1 & 13.7 \\
\hline Yes & 18.4 & 26.8 \\
\hline \multicolumn{3}{|l|}{ Can send SMS } \\
\hline No & 23.7 & 21.1 \\
\hline Yes & 15.8 & 19.5 \\
\hline \multicolumn{3}{|c|}{$\begin{array}{l}\text { Can use Bluetooth or infrared to transfer pictures or anything and } \\
\text { can use to increase my vocabulary }\end{array}$} \\
\hline No & 24.7 & 25.3 \\
\hline Yes & 14.7 & 15.3 \\
\hline \multicolumn{3}{|c|}{ Can search number of specific persons by name } \\
\hline No & 11.1 & 3.2 \\
\hline Yes & 28.4 & 37.4 \\
\hline
\end{tabular}

The average age of participants was 25 years which ranged from 20 to 40 years. 57\% women have no education from Hunza and Nagar such as 20 to 25 (only $1.1 \%$ out of $16 \%$ ); 26 to $30(12.1 \%$ out of $29 \%) ; 31$ to 35 (31.1\% out of $37 \%)$, and 36 to $40(13.1 \%$ out of $17 \%$ ) (as shown in Figure 2 ).

4.2. Access to Mobile Phone. This section addresses the first part of the research question one. The participants were asked questions regarding access to the mobile phone, and $80 \%$ of women said that they own mobile phones and $20 \%$ responded that they do not have a mobile phone. The participants responded on the kinds of mobile phones such as $62.7 \%$ said that they have a simple mobile phone and $17.4 \%$ said that they have a smartphone. On the question of which is the service provider, $5.2 \%$ said that they use the SCOM service, $24.2 \%$ said that they use Telenor, $25.8 \%$ said that they use Zong, and $24.7 \%$ said that they use more than one service provider (detail is shown in Figure 3).

4.3. Skills to Use a Mobile Phone. This section addresses the second part of the research question one. The women of Hunza and Nagar districts were asked questions regarding skills to use a mobile phone. The result showed that $80 \%$ of
TABLE 4: Use of mobile phone in daily life activities.

\begin{tabular}{|c|c|c|c|c|c|}
\hline \multirow{3}{*}{ Questions (1-3) } & \multirow{3}{*}{ Scale } & \multicolumn{4}{|c|}{ Region } \\
\hline & & \multicolumn{2}{|c|}{ Hunza } & \multicolumn{2}{|c|}{ Nagar } \\
\hline & & $N$ & $\%$ & $N$ & $\%$ \\
\hline \multirow{3}{*}{$\begin{array}{l}\text { Keep in touch with } \\
\text { family and friends }\end{array}$} & SA & 0 & 0 & 1 & 1 \\
\hline & $\mathrm{A}$ & 19 & 10 & 22 & 12 \\
\hline & SA & 56 & 29 & 54 & 28 \\
\hline \multirow{5}{*}{ Help you to take picture } & SDA & 1 & 1 & 0 & 0 \\
\hline & DA & 15 & 8 & 16 & 8 \\
\hline & SA & 18 & 9 & 20 & 11 \\
\hline & $\mathrm{A}$ & 26 & 14 & 28 & 15 \\
\hline & SA & 15 & 8 & 13 & 7 \\
\hline \multirow{5}{*}{ Help you to send SMS } & SDA & 2 & 1 & 4 & 2 \\
\hline & $\mathrm{DA}$ & 26 & 14 & 19 & 10 \\
\hline & SA & 14 & 7 & 20 & 11 \\
\hline & $\mathrm{A}$ & 20 & 11 & 23 & 12 \\
\hline & SA & 13 & 7 & 11 & 6 \\
\hline \multicolumn{6}{|l|}{ Questions (4-6) } \\
\hline \multirow{5}{*}{ Record audio/video } & SDA & 3 & 2 & 6 & 3 \\
\hline & $\mathrm{DA}$ & 29 & 15 & 29 & 15 \\
\hline & SA & 21 & 11 & 17 & 9 \\
\hline & A & 17 & 9 & 19 & 10 \\
\hline & SA & 5 & 3 & 6 & 3 \\
\hline \multirow{5}{*}{$\begin{array}{l}\text { Mobile phone has given } \\
\text { quick access to Internet use }\end{array}$} & SDA & 18 & 9 & 30 & 16 \\
\hline & DA & 30 & 16 & 23 & 12 \\
\hline & SA & 5 & 3 & 7 & 4 \\
\hline & A & 15 & 8 & 10 & 5 \\
\hline & SA & 7 & 4 & 7 & 4 \\
\hline \multirow{5}{*}{$\begin{array}{l}\text { Help to listen } \\
\text { Naat/Ginan/songs }\end{array}$} & SDA & 2 & 1 & 2 & 1 \\
\hline & $\mathrm{DA}$ & 6 & 3 & 8 & 4 \\
\hline & SA & 23 & 12 & 22 & 12 \\
\hline & A & 33 & 17 & 31 & 16 \\
\hline & SA & 11 & 6 & 14 & 7 \\
\hline
\end{tabular}

women have skills to switch on and off the mobile phone; can make a call without help (72\%); can load the balance card (52\%); can insert and change the SIM card (69.5\%); can charge the mobile phone $(78.4 \%)$; can insert the mobile battery (71\%); can enter and save contact numbers (45.5\%); can send SMS (35.3\%); can use Bluetooth or infrared to transfer pictures or anything (30\%), and can search a number of a specific person by name (65.8\%).

4.4. Mobile Phone Usage Pattern. The research question two has been addressed in this section. The data were analyzed using the KMO and Bartlett's tests for sampling adequacy and factor analysis technique to explain correlations among multiple outcomes. The estimated results of KMO and Bartlett's response to mobile phone access (MPA), use in daily life activities, skills to use, and use for safety and security purposes are presented in Table 6 .

It is figured out that all the values of $\mathrm{KMO}$ are greater than 0.5 or all the values are greater than 0.8 . These results indicate that samples are adequate and applicable to factor analysis. Also, the estimated probability values of Bartlett's test are presented in the last column of Table 6 . All the $p$ values are less than 0.05 in all the aspects of mobile phone usage. In brief, both KMO and Bartlett's tests suggested that results are statistically significant and reliable for factor analysis. 
TABLE 5: Use of the mobile phone for security purposes.

\begin{tabular}{|c|c|c|c|c|}
\hline \multirow{3}{*}{ Questions (1-3) } & \multicolumn{4}{|c|}{ Region } \\
\hline & \multicolumn{2}{|c|}{ Hunza } & \multicolumn{2}{|c|}{ Nagar } \\
\hline & $N$ & $\%$ & $N$ & $\%$ \\
\hline \multicolumn{5}{|c|}{ Mobile phone has increased the sense of protection while going to bazar } \\
\hline DA & 8 & 4 & 0 & 0 \\
\hline SA & 10 & 5 & 1 & 1 \\
\hline A & 29 & 15 & 31 & 16 \\
\hline SA & 28 & 15 & 45 & 24 \\
\hline \multicolumn{5}{|c|}{ Mobile phone has increased the sense of protection while travelling in public transport } \\
\hline DA & 8 & 4 & 1 & 1 \\
\hline SA & 8 & 4 & 4 & 2 \\
\hline A & 40 & 21 & 37 & 19 \\
\hline SA & 19 & 10 & 35 & 18 \\
\hline \multicolumn{5}{|c|}{ Mobile phone has increased the sense of protection while going for work } \\
\hline $\mathrm{SDA}$ & 1 & 1 & 0 & 0 \\
\hline DA & 9 & 5 & 2 & 1 \\
\hline SA & 23 & 12 & 15 & 8 \\
\hline $\mathrm{A}$ & 28 & 15 & 37 & 19 \\
\hline SA & 14 & 7 & 23 & 12 \\
\hline \multicolumn{5}{|l|}{ Questions (4-5) } \\
\hline \multicolumn{5}{|c|}{ Mobile phone has increased the sense of protection while interacting with unknown people } \\
\hline SDA & 0 & 0 & 5 & 3 \\
\hline $\mathrm{DA}$ & 21 & 11 & 11 & 6 \\
\hline SA & 27 & 14 & 22 & 12 \\
\hline $\mathrm{A}$ & 22 & 12 & 25 & 13 \\
\hline SA & 5 & 3 & 14 & 7 \\
\hline \multicolumn{5}{|c|}{ Mobile phone has increased the sense of protection while alone at home or somewhere else } \\
\hline SDA & 1 & 1 & 3 & 2 \\
\hline DA & 4 & 2 & 4 & 2 \\
\hline SA & 11 & 6 & 7 & 4 \\
\hline A & 41 & 22 & 32 & 17 \\
\hline SA & 18 & 9 & 31 & 16 \\
\hline
\end{tabular}

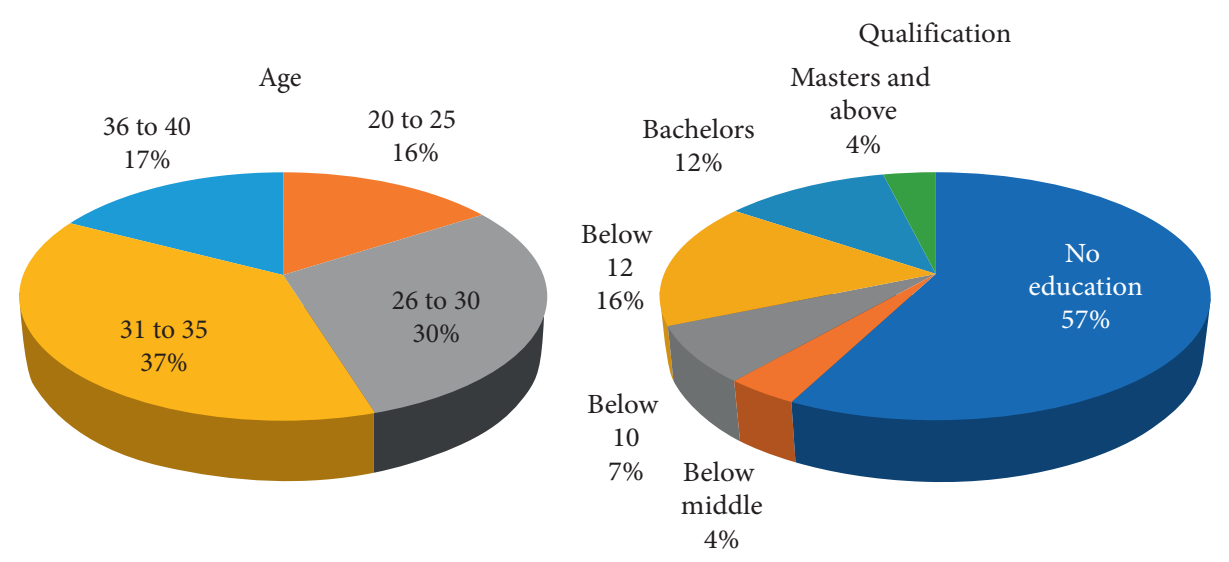

FIgURe 2: Participants' characteristics: age and qualification.

Table 7 shows the estimated results of factor loads and the reliability of scales. Factor analysis has extracted 6 factors of mobile phone access (MPA). We found a higher contribution of the statement "Do you have a mobile phone," and its factor load is .958 in this component. It indicates that the majority of respondents have a mobile phone. The lowest contribution of the statement "How many smartphones do you have in your family?" has also been found to be 0.607 . It also indicates that people are not much sensitive towards more than one smart mobile phone.
We also found a higher factor load of the skills of respondents in mobile phone usage because the entire factor load is greater than 0.8 and each statement is contributing high in this factor. On the other hand, the values of Cronbach's alpha in the second column of Table 8 suggested that the subscales are highly reliable and significant. The highest factor load is 950 of "Making a call without any help from other family members" and lowest factor load is 0.908 which is for "Can use Bluetooth or infrared to transfer pictures or anything". Every component has the highest 


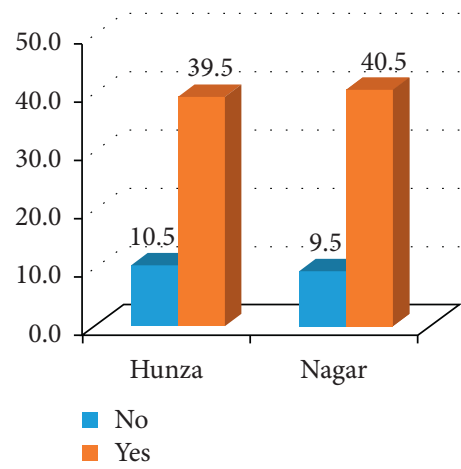

(a)

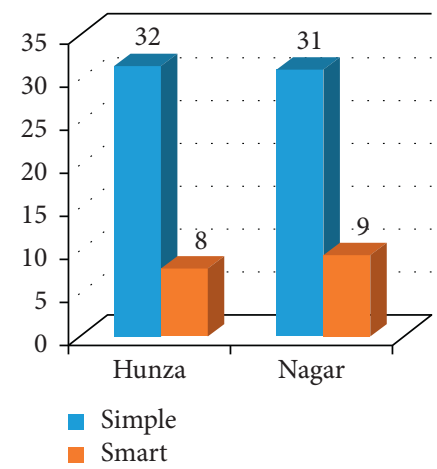

(b)

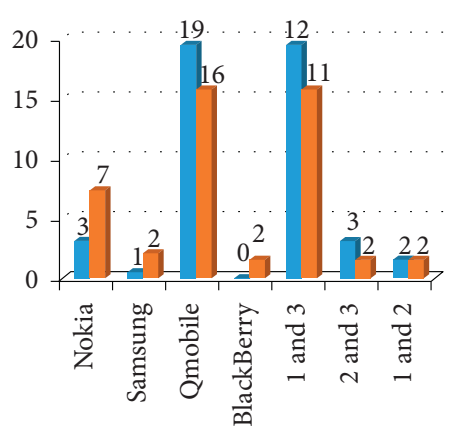

- Hunza

n Nagar

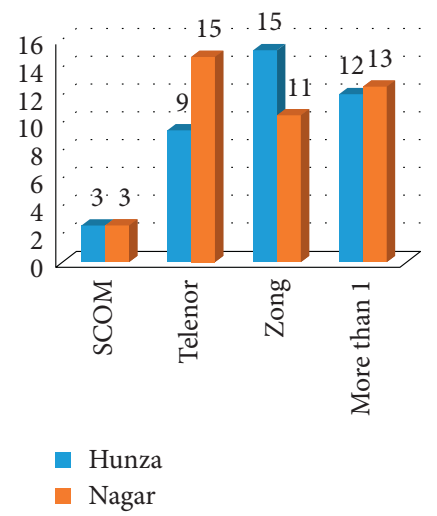

(c)

(d)

Figure 3: (a) Access of the mobile phone, (b) kinds of the mobile phone, (c) brand of the mobile phone, and (d) the service provider.

TABLe 6: KMO and Bartlett's test.

\begin{tabular}{lccr}
\hline Variables & KMO & Bartlett's test of sphericity & Sig \\
\hline MP_Access & 0.910 & 1607.687 & 0.000 \\
MPU_Daily_Life_Activities & 0.907 & 1664.807 & 0.000 \\
MPU_Security & 0.899 & 1309.195 & 0.000 \\
MP_Skills & 0.954 & 4295.132 & 0.000 \\
\hline
\end{tabular}

TABLe 7: Mobile phone access and use in daily life activities.

\begin{tabular}{lc}
\hline Variables & Factor loads \\
\hline Mobile phone access & \\
Do you have mobile phone? & 0.958 \\
What kind of mobile phone do you have? & 0.864 \\
How many mobile phones do you have in your family? & 0.876 \\
How many smartphones do you have in your family? & 0.607 \\
Mobile phone brand & 0.794 \\
Which is your service provider? & 0.735 \\
\hline
\end{tabular}

contribution towards the skills of mobile phone usage (detail is shown in Table 8).

There are 8 factors extracted for mobile phone usage in daily life activities (MPU_Daily_Life_Activities), and the statement contributing the most in this component is "Keep in touch with family" having a factor load of .942. These results indicate that all the statements contribute almost higher than .8, so mobile phone usage has greater importance in their daily life activities. Additionally, the statement contributing higher in mobile phone usage in daily activities is "Help you to send SMS" having a factor load of .937. It indicates that the majority of respondents are using SMS services in their daily life activities (results are shown in Table 9). The estimated coefficients of reliability (Cronbach's 
TABLE 8: Mobile phone usage skills of the women of Hunza and Nagar.

\begin{tabular}{lc}
\hline Variables & Factor loads \\
\hline Mobile phone usage skills & 0.948 \\
Can switch on/off mobile phone & 0.950 \\
Make a call without help & 0.918 \\
Can load balance card & 0.947 \\
Can insert and change SIM card & 0.949 \\
Can charge my mobile phone & 0.947 \\
Can search number of specific persons by name & 0.935 \\
Can insert mobile battery & 0.920 \\
Can enter and save a number of any person to my contact list & 0.909 \\
Can send SMS & 0.908 \\
Can use Bluetooth or infrared to transfer pictures or anything & 0.983 \\
\hline
\end{tabular}

TABle 9: Use of mobile phone in daily life activities.

\begin{tabular}{ll}
\hline Variables & Factor loads \\
\hline Mobile phone daily life activities & \\
Keep in touch with family & 0.942 \\
Keep in touch with friends & 0.938 \\
Help you to take picture & 0.920 \\
Help you to send SMS & 0.937 \\
Record audio video & 0.922 \\
Mobile phone has given quick access to the Internet and use Internet & 0.856 \\
Help to listen Naat/Ginan/songs & 0.886 \\
\hline
\end{tabular}

alphas) of all the variables are presented in the last column of Table 9. These values suggested that subscales of mobile phone usage are highly reliable.

In the section, there are 5 factors extracted for mobile phone usage for safety and security purposes, and the statement contributing the most in this component is "Mobile phone has increased the sense of protection while going to the bazar" having a factor load of .963 and the lowest is .928 which is "Mobile phone has increased the sense of protection while interacting with unknown people". All the statements contribute almost higher than 0.9 (detail is shown in Table 10).

\section{Discussion}

The potential of mobile phones cannot be ignored, which improves access to information and services especially in lowresourced settings [21, 22]. The use of conventional mobile phone technologies to support daily life activities such as phone calls, SMS, wake up rings, and access to the Internet is found to be very useful for rural women [49]. This study revealed that young women's effective use of mobile phones helped them to ensure self-security in existing security threats in the Pakistani society which has been widely acknowledged in the literature [48]. Besides business activities, mobile phones have also affected human life. For example, rural women started using mobile phones in their daily life and developed their skills to use it for multiple purposes. Most of the women from both districts (Hunza and Nagar) own mobile phones. In this context, however, there is no barrier from the part of their families as compared to other parts of the country. But, very few respondents showed concern about misuse of mobile phones such as receiving unethical messages, wrong calls, and people's misperception of using mobile phones which appeared to be some of the barriers in using mobile phones freely to engage themselves with boosting business activities in the region.

The survey of the research shows that $57 \%$ of women are illiterate while they have the skills to use a mobile phone. In addition, they frequently and properly use mobile phones for business purposes at different levels. Hence, the usage of mobile phones is mainly for productive activities, i.e., for income generation and livelihood activities. On the contrary, the study results show that a huge number of unskilled workforce, i.e., about $57 \%$ in the study area, would be directly affected in the future due to the China-Pakistan Economic Corridor (CPEC) which is expected to change the dynamics of the existing business. Therefore, future research needs to focus on the various skills required for modern business. Therefore, all the mobile phone users in the region should focus on enhancing the technical skills required for an online business, for example, freelancing and e-commerce. In addition, there is a need to increase the different skills of women to boost up business activities through the use of mobile phones which would ultimately promote developmental activities in the region. However, in Pakistan, the service providers have already established the mobile phone infrastructure both in urban and rural remote areas of Gilgit-Baltistan that would help the people especially females to access mobile phones [56]. Lastly, new innovative business ventures and enhancement of business activities are possible by providing proper training on skill development and effective use of the mobile phone to $57 \%$ unskilled women in the study area. 
TABLE 10: Mobile phone use for security purposes.

\begin{tabular}{lc}
\hline Variables & Factor loads \\
\hline MPU_Security & 0.963 \\
Mobile phone has increased the sense of protection while going to bazar $\alpha$ \\
Mobile phone has increased the sense of protection while travelling in public transport & 0.953 \\
Mobile phone has increased the sense of protection while going for work & 0.947 \\
Mobile phone has increased the sense of protection while interacting with unknown people & 0.928 \\
Mobile phone has increased the sense of protection while alone at home or somewhere else & 0.940 \\
\hline
\end{tabular}

5.1. Limitation and Future Direction of Research. This study has provided some significant empirical shreds of evidence regarding the access to mobile phones and skills and use of the mobile phone for business purposes [57] by rural mountainous women of GB. There are some limitations such as the current study only focused on the usage of mobile phones for business purposes [58], security, communication, and access to information. However, the use of mobile phone in areas such as health, education, sociocultural, knowledge sharing, and professional development, and in sum all fields of life, is highly dependent upon the effective use of mobile phones [59]. Similarly, there are many other devices such as iPads, Tablets, PCs, Palm devices, and laptops which can also be used for these activities that this study did not focus. In the future, the research may focus on the use of mobile phones in a diverse range of its applications and its impact on the overall quality of life. Future research needs to focus on psychological issues and the negative impact of the mobile phone usage among the women of Gilgit-Baltistan.

\section{Conclusion}

The present study focuses on exploring the access and usage of a mobile phone in the daily life of rural women of two districts, i.e., Hunza and Nagar of Gilgit-Baltistan, Pakistan. For this purpose, the data are collected from 200 women through a questionnaire. The results of the study revealed that most of the women in the study area possess a mobile phone, and they use it for productive purposes. Furthermore, $37 \%$ women of age $31-35$ years and $30 \%$ of age $26-30$ years have access to mobile phones. However, the lowest users of mobile phones are the women aged 36-40 (17\%) and women aged 20-25 years (16\%). This shows that higher-aged women use mobile phones more than the youngsters. The women of rural Hunza and Nagar use mobile phones for various purposes, i.e., security, entertainment, communication, and sharing of knowledge. Moreover, the outcomes of the study reveal that women feel more comfortable by having a mobile phone which enhanced their level of confidence. On the contrary, the findings also show that $57 \%$ of the female population of the region is illiterate though they can use a mobile phone for everyday activities such as communication. However, fewer participants misuse the mobile phone, which needs to be discouraged, and they should focus on using this technology for improving the quality of life and productive purpose.

\section{Data Availability}

The survey data used to support the findings of this study are included within the article.

\section{Conflicts of Interest}

The authors declare that they have no conflicts of interest.

\section{References}

[1] S. Chatterjee, "A sociological outlook of mobile phone use in society," International Journal of Interdisciplinary and Multidisciplinary Studies (IJIMS), vol. 4, pp. 59-63, 2014.

[2] J. E. Katz and M. Aakhus, Perpetual Contact: Mobile Communication, Private Talk, Public Performance, Cambridge University Press, Cambridge, UK, 2002.

[3] J. E. Katz, "Mobile phones as fashion statements: the Cocreation of mobile communication's," in Magic in the Air, pp. 79-100, Routledge, Abingdon, UK, 2017.

[4] J. E. Katz and S. Sugiyama, "Mobile phones as fashion statements: the co-creation of mobile communication's public meaning," in Mobile Communications, pp. 63-81, Springer, Berlin, Germany, 2005.

[5] K. Aoki and E. J. Downes, "An analysis of young people's use of and attitudes toward cell phones," Telematics and Informatics, vol. 20, no. 4, pp. 349-364, 2003.

[6] L. Fortunati, "The mobile phone: towards new categories and social relations," Information, Communication \& Society, vol. 5, no. 4, pp. 513-528, 2002.

[7] T. Kreutzer, "Assessing cell phone usage in a South African township school," International Journal of Education and Development Using ICT, vol. 5, pp. 43-57, 2009.

[8] UNESCO, Mobile Phones \& Literacy, Empowerment in Women's Hands, UNESCO Publishing United Nations, Paris, France, 2015.

[9] GSMA, The Mobile Gender Gap Report, GSMA,London, UK, 2019, https://www.gsma.com/mobilefordevelopment/wpcontent/uploads/2019/02/GSMA-The-Mobile-Gender-GapReport-2019.pdf.

[10] PTA, “Annual report,” 2019, https://www.pta.gov.pk.

[11] WorldBank, “Annual Report," 2014, https://www.worldbank. org.

[12] G. Sylvester, Use of Mobile Phones by the Rural Poor: Gender Perspectives from Selected Asian Countries, IDRC, Ottawa, ON, CA, 2016.

[13] A. S. Nurullah, "The cell phone as an agent of social change," Rocky Mountain Communication Review, vol. 6, pp. 19-25, 2009.

[14] M. Javid, M. A. Malik, and A. A. Gujjar, "Mobile phone culture and its psychological impacts on students' learning at the university level," Language in India, vol. 11, 2011. 
[15] UNCTAD, "United nations conference on trade and development," Review of Maritime Transport, UNCTAD, Geneva, Switzerland, 2014.

[16] A. Bhavnani, R. W.-W. Chiu, S. Janakiram, P. Silarszky, and D. Bhatia, "The role of mobile phones in sustainable rural poverty reduction," Retrieved November, vol. 22, 2008.

[17] S. Wyche and J. Olson, "Gender, mobile, and mobile Internet| Kenyan women's rural realities, mobile internet access, and "africa rising"” Information Technologies \& International Development, vol. 14, no. 15, 2018.

[18] C. Z.-W. Qiang, "Mobile telephony: a transformational tool for growth and development," Private Sector \& Development, vol. 4pp. 7-8, 2009.

[19] ADB, "Sustainable development challenges," World Economic and Social Survey 2013, ADB, Mandaluyong, Philippines, 2013.

[20] Z. Laizu, J. Armarego, and F. Sudweeks, "Cognitive change in women's empowerment in rural Bangladesh," in Proceedings of the 13th International Conference on Computer and Information Technology (ICCIT), pp. 277-282, Dhaka, Bangladesh, December 2010.

[21] J. Gikas and M. M. Grant, "Mobile computing devices in higher education: student perspectives on learning with cellphones, smartphones \& social media," The Internet and Higher Education, vol. 19, pp. 18-26, 2013.

[22] S. Misra, L. Cheng, J. Genevie, and M. Yuan, "The iPhone Effect," Environment and Behavior, vol. 48, no. 2, pp. 275-298, 2016.

[23] G. Demombynes and A. Thegeya, Kenya's Mobile Revolution and the Promise of Mobile Savings, The World Bank, Washington, DC, USA, 2012.

[24] L. Caronia and A. H. Caron, "Constructing a specific culture: young people's use of the mobile phone as a social performance," Convergence: The International Journal of Research Into New Media Technologies, vol. 10, no. 2, pp. 28-61, 2004.

[25] ITU, UN's International Telecommunication Union (ITU), ITU, Geneva, Switzerland, 2019, https://www.itu.int/en/ publications/Pages/default.aspx.

[26] H. E. Chew, P. Vigneswara Ilavarasan, and M. R. Levy, “A latency effect for mobile phone investments by micro-entrepreneurs," Media Asia, vol. 39, no. 2, pp. 99-108, 2012.

[27] S. Bailur, S. Masiero, and J. Tacchi, "Gender, mobile, and mobile internet| gender, mobile, and development: the theory and practice of empowerment-Introduction," Information Technologies \& International Development, vol. 14, no. 9, 2018.

[28] Cherie Blair Foundation, Women \& Mobile: A Global Opportunity, A Study on the Mobile Phone Gender Gap in Low and Middle-Income Countries, GSMA, London, UK, 2017.

[29] S. A. Asongu, J. C. Nwachukwu, and A. Aziz, "Determinants of mobile phone penetration: panel threshold evidence from sub-Saharan Africa," Journal of Global Information Technology Management, vol. 21, no. 2, pp. 81-110, 2018.

[30] W. M. Olatokun, "Availability, accessibility and use of ICTs by Nigerian women academics," Malaysian Journal of Library \& Information Science, vol. 12, pp. 13-33, 2017.

[31] E. Buja, "Hofstede's dimensions of national cultures revisited: a case study of South Korea's culture," Acta Universitatis Sapientiae, Philologica, vol. 8, no. 1, pp. 169-182, 2016.

[32] A. A. Shaikh and H. Karjaluoto, "Mobile banking adoption: a literature review," Telematics and Informatics, vol. 32, no. 1, pp. 129-142, 2015.

[33] E. L. Slade, M. D. Williams, and Y. K. Dwivedi, "Mobile payment adoption: classification and review of the extant literature," The Marketing Review, vol. 13, no. 2, pp. 167-190, 2013.

[34] Z. Laizu, J. Armarego, and F. Sudweeks, "The role of ICT in women's empowerment in rural Bangladesh," in Proceedings of the Cultural Attitudes Towards Communication and Technology 2010, pp. 217-230, Murdoch, Australia, June 2010.

[35] M. A. Islam and K. M. G. Hoq, "Community Internet access in rural areas: a study on community information centres in Bangladesh," Malaysian Journal of Library \& Information Science, vol. 15, pp. 109-124, 2017.

[36] K. B. Leahy and I. Yermish, "Information and communication technology: gender issues in developing nations," Informing Science, vol. 6, pp. 143-155, 2003.

[37] UNESCO, Shaping the Future Education through Mobile Phone, Nokia and UNESCO Pakistan, Islamabad, Pakistan, 2017.

[38] B. Reema and S. Sambargi, "Evaluation of personal innovativeness and perceived expertise on digital marketing adoption by women entrepreneurs of micro and small enterprises," International Journal of Research and Analytical Reviews, vol. 6, no. 1, pp. 338-351, 2019.

[39] D. Potnis, "Culture's consequences: economic barriers to owning mobile phones experienced by women in India," Telematics and Informatics, vol. 33, no. 2, pp. 356-369, 2016.

[40] E. R. Mbise, A. F. Kapinga, and C. S. Montero, "Mobile marketing application for entrepreneurship development: codesign with women entrepreneurs in Iringa," EJISDC, vol. 85, no. 2, 2018.

[41] A. Doron, "Mobile persons: cell phones, gender and the self in North India," The Asia Pacific Journal of Anthropology, vol. 13, no. 5, pp. 414-433, 2012.

[42] A. R. Madni, G. Ali, M. Abdullah, and S. Batool, "Mobile phone-need or status sybmol:(exploring usage \& liking of mobile connections and packages by university students)," Global Media Journal, vol. 7, 2014.

[43] G. Porter, K. Hampshire, A. Abane et al., "Mobile phones, gender, and female empowerment in sub-saharan Africa: studies with African youth," Information Technology for Development, vol. 26, no. 1, pp. 1-14, 2019.

[44] J. C. Aker, C. Ksoll, and T. J. Lybbert, "ABC, 123: the impact of a mobile phone literacy program on educational outcomes," SSRN Electronic Journal, 2010.

[45] E. E. Baro and B.-e. C. Endouware, "The effects of mobile phone on the socio-economic life of the rural dwellers in the Niger Delta region of Nigeria," Information Technology for Development, vol. 19, no. 3, pp. 249-263, 2013.

[46] S. Malik, I. S. Chaudhry, and Q. Abbas, "Socio-economic impact of cellular phones growth in Pakistan: an empirical analysis," Pakistan Journal of Social Sciences (PJSS), vol. 29, pp. 23-37, 2009.

[47] S. Mittal, S. Gandhi, and G. Tripathi, "Socio-economic impact of mobile phones on Indian agriculture," Working Paper. 246, Indian Council for Research on International Economic Relations, New Delhi, India, 2010.

[48] K. R. A Bairagi, T. S. Polin, and A. Terrence, "Socio-economic impacts of mobile phone in rural Bangladesh: a case study in batiaghata thana, khulna district anupam," M.Sc thesis, The University of Hong Kong, Pokfulam, Hong Kong, 2011.

[49] S. A. Asongu, "How has mobile phone penetration stimulated financial development in africa?" Journal of African Business, vol. 14, no. 1, pp. 7-18, 2013.

[50] R. Ling and T. Bertel, "Mobile communication culture among children and adolescents," The Routledge International Handbook of Children, Adolescents and Media, pp. 127-133, Routledge, Abingdon, UK, 2013.

[51] T. Page, "Touchscreen mobile devices and older adults: a usability study," International Journal of Human Factors and Ergonomics, vol. 3, no. 1, pp. 65-85, 2014. 
[52] J. P. Rossing, W. Miller, A. K. Cecil, and S. E. Stamper, "iLearning: the future of higher education? student perceptions on learning with mobile tablets," Journal of the Scholarship of Teaching and Learning, vol. 12, no. 2, pp. 1-26, 2012.

[53] M. Hakoama and S. Hakoyama, "The impact of cell phone use on social networking and development among college students," The American Association of Behavioral and Social Sciences Journal, vol. 15, p. 20, 2011.

[54] A. D. Alanazi, The Use of the Smartphones as a Resource for News Among Saudi Arabian Students in the United States, Indiana University of Pennsylvania, Indiana, PA, USA, 2014.

[55] M. Sánchez-Martínez and A. Otero, "Factors associated with cell phone use in adolescents in the community of madrid (Spain)," CyberPsychology \& Behavior, vol. 12, no. 2, pp. 131-137, 2009.

[56] J. O. T. A. Watkins, J. Goudge, F. X. Gómez-Olivé, and F. Griffiths, "Mobile phone use among patients and health workers to enhance primary healthcare: a qualitative study in rural South Africa," Social Science \& Medicine, vol. 198, pp. 139-147, 2018.

[57] L. F. Motiwalla, "Mobile learning: a framework and evaluation," Computers \& Education, vol. 49, no. 3, pp. 581-596, 2007.

[58] D. Raftery, "Ubiquitous mobile use: student perspectives on using the VLE on their phone," Irish Journal of Technology Enhanced Learning, vol. 3, no. 2, pp. 47-57, 2018.

[59] C. Kaatz, C. Brock, and L. Figura, "Are you still online or are you already mobile? - predicting the path to successful conversions across different devices," Journal of Retailing and Consumer Services, vol. 50, pp. 10-21, 2019. 